\title{
Photo tow: a new method for estimating coral reef status and changes at large spatial scale. A coral bleaching event case study
}

Yannick Chancerelle, Robert Maurin, Sébastien Poujade et Caroline Vieux

\section{(2) OpenEdition}

Journals

Édition électronique

URL : http://journals.openedition.org/jso/3312

DOI : $10.4000 /$ jso.3312

ISSN : $1760-7256$

Éditeur

Société des océanistes

Édition imprimée

Date de publication : 15 décembre 2008

Pagination : 67-74

ISBN : 978-2-85430-012-3

ISSN : 0300-953x

Référence électronique

Yannick Chancerelle, Robert Maurin, Sébastien Poujade et Caroline Vieux, "Photo tow: a new method

for estimating coral reef status and changes at large spatial scale. A coral bleaching event case study », Journal de la Société des Océanistes [En ligne], 126-127 | Année 2008, mis en ligne le 15 décembre 2011, consulté le 17 juin 2020. URL : http://journals.openedition.org/jso/3312 ; DOI : https://doi.org/10.4000/jso.3312 


\title{
Photo tow: a new method for estimating coral reef status and changes at large spatial scale. A coral bleaching event case study
}

by

\author{
Yannick CHANCERELLE, Robert MAURIN, Sébastien POUJADE \\ and Caroline VIEUX*
}

\begin{abstract}
Refering to a coral bleaching event that took place in French Polynesia in 2002, and in order to document the health of the coral reef outer slope at a scale of several tens of kilometers of coastline, we developed a new method on the island of Moorea. This method consists of monitoring the reef at constant depth by towing, behind a boat, a scuba diver operating a photographic camera. This method enables precise and fast scanning of the reef at regular intervals along a great distance. In the case of the study presented here, geographical differences were found around the island: healthy coral cover was greater on the north coast, and bleaching intensity was greatest on the north-west coast.
\end{abstract}

KEYWORDs: coral bleaching, French Polynesia, island scale sampling, method

In order to establish the health status of coral reefs, many previous papers on reef sampling strategy in monitoring programs clearly demonstrate the importance of integrating multiple scales of study (Edmunds and Bruno, 1996; Edmunds, 2002; Miller et al., 2002, Ninio and Meekan, 2002; Adjeroud et al., 2005; Chabanet et al., 2005). One possible way to take into

\section{RÉSUMÉ}

À l'occasion d'un phénomène de blanchissement corallien survenu en 2002 en Polynésie française et afin de réaliser des relevés de l'état de santé du récif corallien à l'échelle de plusieurs dizaines de kilomètres de linéaire côtier sur les pentes externes de l'île de Moorea, une méthode originale a été expérimentée. Elle consiste à réaliser des relevés réguliers du récif à profondeur constante en tractant, avec un bateau, un plongeur porteur d'un dispositif photographique. Elle permet la réalisation de relevés à la fois précis, rapides et sur de longues distances. Dans le cas présenté ici, des différences géographiques ont été mises en évidence autour de l'île en ce qui concerne le recouvrement corallien, plus dense sur la côte nord, et l'intensité du blanchissement plus important sur la côte nord-ouest.

MOTS-CLÉS : blanchissement corallien, Polynésie française, échantillonage à l'échelle insulaire, méthode

account local-scale variability on an island coral reef ecosystem is to select several sampling sites around each island, thus defining a hierarchical sampling design. Most ecological field studies on coral reefs use methods with restricted sample unit size: 25 to $50 \mathrm{~m}$ for linear methods which consist in noting what organism (coral, algae, echinid, mollusk...) or substrate (sand, rubble,

* Centre de recherches insulaires et observatoire de l'environnement, uMs 2978 CNRS-EPHE, Moorea (Polynésie française), criobe@mail.pf 
turf...) are at regular intervals (e.g.: Loya, 1978; Marsh et al., 1984; Mc Manus et al., 1997), 0.25 to $4 \mathrm{~m}^{2}$ for quadrat methods which consist in an evaluation of the surface occupied by organisms or categories of substrate (e.g.: Connell, 1973; 1976; English et al., 1997; Hanisak et al., 1989; Aronson et al., 1994). They are suitable for the sampling of reefs from reefscape to reef zone scales (Chabanet et al., 2005) but always considering very small parts of the reef ecosytem. They become problematic for larger scale studies at whole reef or island scales, from $1 \mathrm{~km}$ to $100 \mathrm{~km}$ (Chabanet et al., 2005). Manta tow surveys (Kenchington, 1978; English et al., 1997) have been conceived to prospect large area of reefs: a diver is towed by a boat and notes abundances of coral coverage according to a scale. This method is more efficient for covering large areas but is relatively inaccurate. In the context of such ecological studies, airborne and satellite remote sensing (Maragos and Cook, 1995; Ammenberg et al., 2002; Andréfouët et al., 2002; Yamano and Tamura, 2002; Yamano et al., 2002; Mumby et al., 2004) could also be relevant for the rapid detection of kilometer-wide variations, but these techniques provide no higher resolution than manta tow surveys, are depth limited, and often expensive. Fast and accurate reef surveys would certainly benefit several reef monitoring programs at the whole reef scale or island scale (Chabanet et al., 2005).

The time period available to study quantitative (e.g., percent coral cover) and qualitative (e.g., coral genus diversity) change on reefs following short disturbances such as cyclones, heavy swells, or even bleaching events is often limited and surveys cannot be done both accurately and at large scale by using the currently available methods mentioned above. To address this problem, we have developed a new method for monitoring large scale coral percentage covers and diversity and for optimizing the efficiency ratio (scanning area size $v s$ scanning time) of surveys. Our method, called "photo tow», has been tested in the field during the moderate bleaching event that hit the reefs of Moorea (French Polynesia) from April to July 2002. We present here the technical aspects of the photo tow method and its effectiveness to assess the bleaching and coverage status of coral around the whole reef of Moorea island in 2002.

\section{Methods}

Moorea, sister island of Tahiti, is a volcanic island located in the Society Archipelago $\left(17^{\circ} 32^{\prime} / 149^{\circ} 50\right)$. It is one of the 118 islands of French Polynesia (figure 1). It covers a surface of $132 \mathrm{~km}^{2}$ and is surrounded by a $55 \mathrm{~km}$ barrier reef faced to the ocean with an outer slope where the maximum coral reef cover occurs in a complex reef ecosystem. This barrier reef is interrupted by 11 passes. The photo tow method was implemented for a fast assessment of the bleaching status on the outer slopes of the whole island during the coral bleaching event that occurred from April to July 2002. Bleaching events occur when the sea surface temperature is warmer than usual during summer time. Corals are living near the lethal maximum temperature they can support. When the temperature is 1 to $2^{\circ} \mathrm{C}$ above $29^{\circ} \mathrm{C}$ during some weeks, there is a rupture of the symbiosis between the coral and its endosymbiotic dinoflagellate algae which are expulsed. The coral get white because of the loss of these zooxanthellae and because its white skeleton appears through its transparent tissues.

The technique involves towing a scuba diverphotographer at constant low speed (2-3 knots) by a boat using a $16 \mathrm{~m}$ rope and a «manta board» (English et al., 1997). The board $(15 \times 23 \times$ 1 inches) supports a camera (Nikonos V, $15 \mathrm{~mm}$ lens), two strobe lights, a depth meter and a hand scuba-echosonar (figure 2). On the boat, an echosonar allows the pilot to maintain the track at a constant depth along the slope. A $10 \mathrm{~m}$ depth was chosen for surveys, as theoretically, the maximum coral coverage and diversity occurs at this depth. The scuba-echosonar allows the diver to stay at a constant depth during the dive. The boat slows down every 2 minutes for 30 seconds allowing the diver to take a photography of the reef. The distance between the camera and the sea floor is set at $3 \mathrm{~m}$ by using the echosonar. The position (GPS and map) and time of each photography are recorded on the boat. The spatial distance between the 2 photographies is approximately $200 \mathrm{~m}$.

The total number of photographies taken around the outer slope reefs of Moorea $(55 \mathrm{~km})$ was 275. Passes were not sampled because of different environmental and geomorphological features. The total time spent on the field with 2 divers and a boat driver was 5 days, so approximately 30 hours were spent, by 3 persons each for the complete survey of all the island.

At the laboratory each picture is scanned and analyzed using Coral Point Count software (Kolher, 2004) with Excel extension. It consists report, on a punctuated network, how many living coral colonies are present, noting if they are normal or bleached. This software allows a random point projection for the application of 


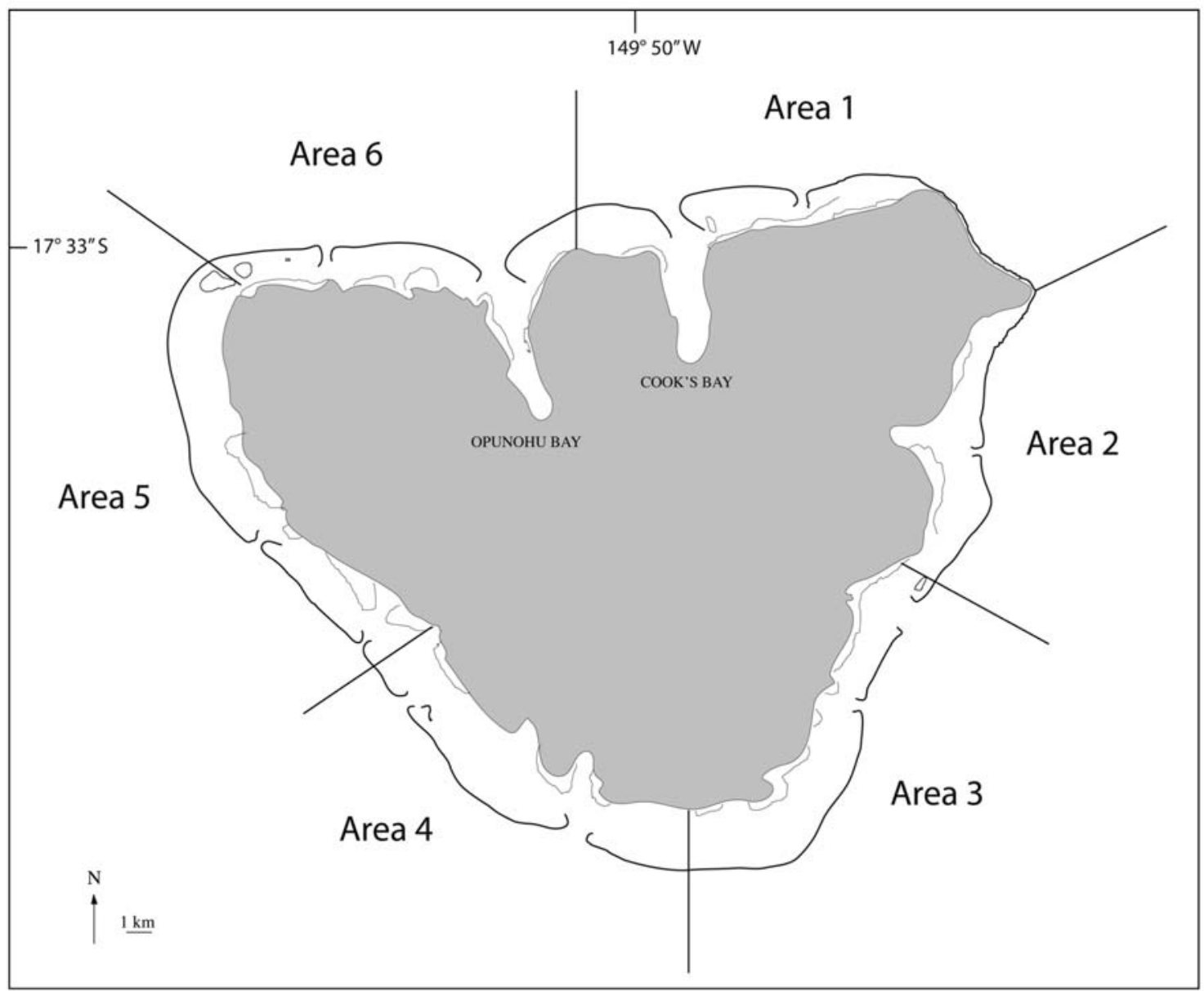

FIGURE 1. - Moorea map divided into 6 areas. In each of the area, 30 couples of values (coral percent cover and bleaching ratio) are randomly sampled for statistical analysis of the data

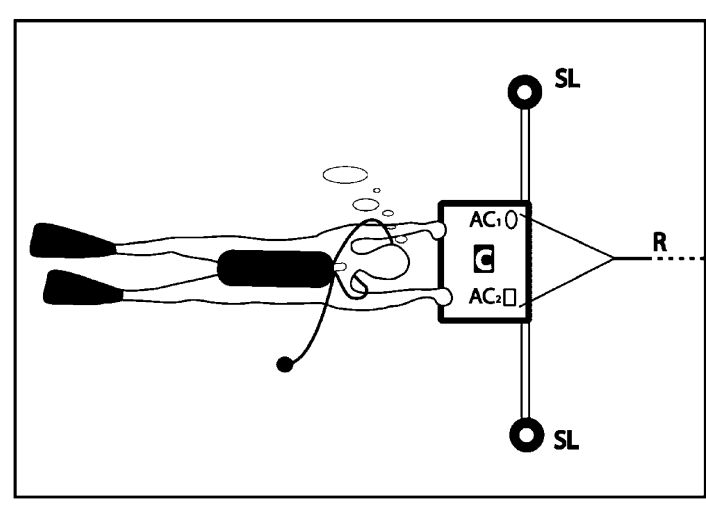

FIGURE 2. - Representation of Photo-tow device including a scuba diver-operator, board, camera (C), strobe lights (SL), rope (R) and vertical location accessories (AC1 and $\mathrm{AC} 2)$

the point intercept method (Loya, 1978) on the pictures. Coral percent cover $(100 \times$ number of points with live coral / total number of points counted $)$ and bleaching ratio $(100 \times$ number of points with bleached coral / total number of points with live coral) are obtained in this way.
Because coral cover and bleaching rate differences are suspected along the coast, data sets were divided into 6 geographic areas (figure 1). Paired coral percent cover and bleaching ratio were randomly sampled. Mean and standard errors of 30 values were calculated for each geographic area. Anova with Student-NewmanKeuls tests were used to test significant differences between areas for coral percentage and bleaching ratio.

\section{Results and discussion}

The means of coral percent cover varied among the different studied areas (figure 3 and table 1). The north coast had the highest coral coverage with means of $46.83 \% \pm 6.32$ and 43 . $83 \% \pm 5.86$ respectively for area 1 and area 6 . On the east coast, coral coverage was lower with mean values $35.50 \% \pm 2.56$ and $34.50 \% \pm 5.62$ for area 2 and 3 respectively. The west coast showed a gradient with increasing values from 
south to north (area 4: $25.33 \% \pm 3,14$, area 5: $30.83 \% \pm 2.65$; area 6: $46.83 \% \pm 6.32$ ). Student-Newman-Keuls tests showed significant differences for area 1 vs areas 2, 3, 4, 5 and for area 6 vs areas 4 and 5 (Table 2) and confirm the general trend of the figure 3 , with highest values on the whole north shore of Moorea.

The means of bleaching ratios cover varied among the different studied areas (figure 4 and table 1) but were quite similar from the north east to the south corner of the island (area 1:
$11,74 \% \pm 3,02$, area $2: 12,96 \% \pm 3,18$, area 3 : $9,58 \% \pm 3,07)$. From the South corner to the North West corner of the island, the bleaching rate increased (area 4: $11.73 \% \pm 4.24 \%$, area 5: $18.39 \% \pm 4.95$, area 6: $23.39 \% \pm 8.91$ ). Student-Newman-Keuls tests showed significant differences for area 6 vs area 1, 2, 3, 4 (Table 3) and confirm the trend of figure 4 with highest values of bleaching intensity located on the north west part of Moorea.

\begin{tabular}{lcccc}
\hline & Degrees of freedom & Mean Square & F-value & P-value \\
\hline Coral Coverage & 5 & 815,548 & 3,809 & 0,0027 \\
Bleaching Ratio & 5 & 214,136 & 6,945 & $<0,0001$ \\
\hline
\end{tabular}

TABLE 1. - ANOVA result for coral percent coverage and bleaching ratio means comparison among the 6 sampling areas

\begin{tabular}{c|ccccc} 
Area & $\mathbf{2}$ & $\mathbf{3}$ & $\mathbf{4}$ & $\mathbf{5}$ & 6 \\
\hline 1 & $11,333^{*}$ & $12,333^{*}$ & $21,500^{*}$ & $16,000^{*}$ & 3,000 \\
& 10,203 & 11,203 & 12,447 & 11,903 & 8,508 \\
$\mathbf{2}$ & & 1,000 & 10,167 & 4,667 & $-8,333$ \\
& & 8,508 & 11,203 & 10,203 & 8,508 \\
$\mathbf{3}$ & & & 9,167 & 3,667 & $-9,333$ \\
& & & 10,203 & 8,508 & 10,203 \\
$\mathbf{4}$ & & & & $-5,500$ & $-18,500 *$ \\
& & & & 8,508 & 11,903 \\
$\mathbf{5}$ & & & & & $-13,000 *$ \\
& & & & & \\
& & & & & \\
& & & & &
\end{tabular}

TABLE 2. - Pairwise comparisons among the 6 sampling areas of percent of coral cover means based on Student-Newman-Keuls analysis

\begin{tabular}{|c|c|c|c|c|c|}
\hline Area & 2 & 3 & 4 & 5 & 6 \\
\hline 1 & $-1,221$ & 2,160 & 0,007 & $-6,6651$ & $-11,651 *$ \\
\hline & 7,469 & 8,958 & 7,469 & 8,958 & 9,835 \\
\hline 2 & & $\begin{array}{l}3,381 \\
9,835\end{array}$ & $\begin{array}{l}1,228 \\
8,958\end{array}$ & $\begin{array}{c}-5,430 \\
7,469\end{array}$ & $\begin{array}{c}-10,430 * \\
8,958\end{array}$ \\
\hline 3 & & & $\begin{array}{l}-2,153 \\
7,469\end{array}$ & $\begin{array}{l}-8,811 \\
10,450\end{array}$ & $\begin{array}{c}-13,811 * \\
10,927\end{array}$ \\
\hline 4 & & & & $\begin{array}{l}-6,658 \\
9,835\end{array}$ & $\begin{array}{c}-11,658 * \\
10,450\end{array}$ \\
\hline 5 & & & & Indicate & $\begin{array}{c}-5,000 \\
7,469 \\
\text { cant values. }\end{array}$ \\
\hline
\end{tabular}

TABLE 3. - Pairwise comparisons among the 6 sampling areas of percent of bleaching ratio means based on Student-NewmanKeuls analysis 


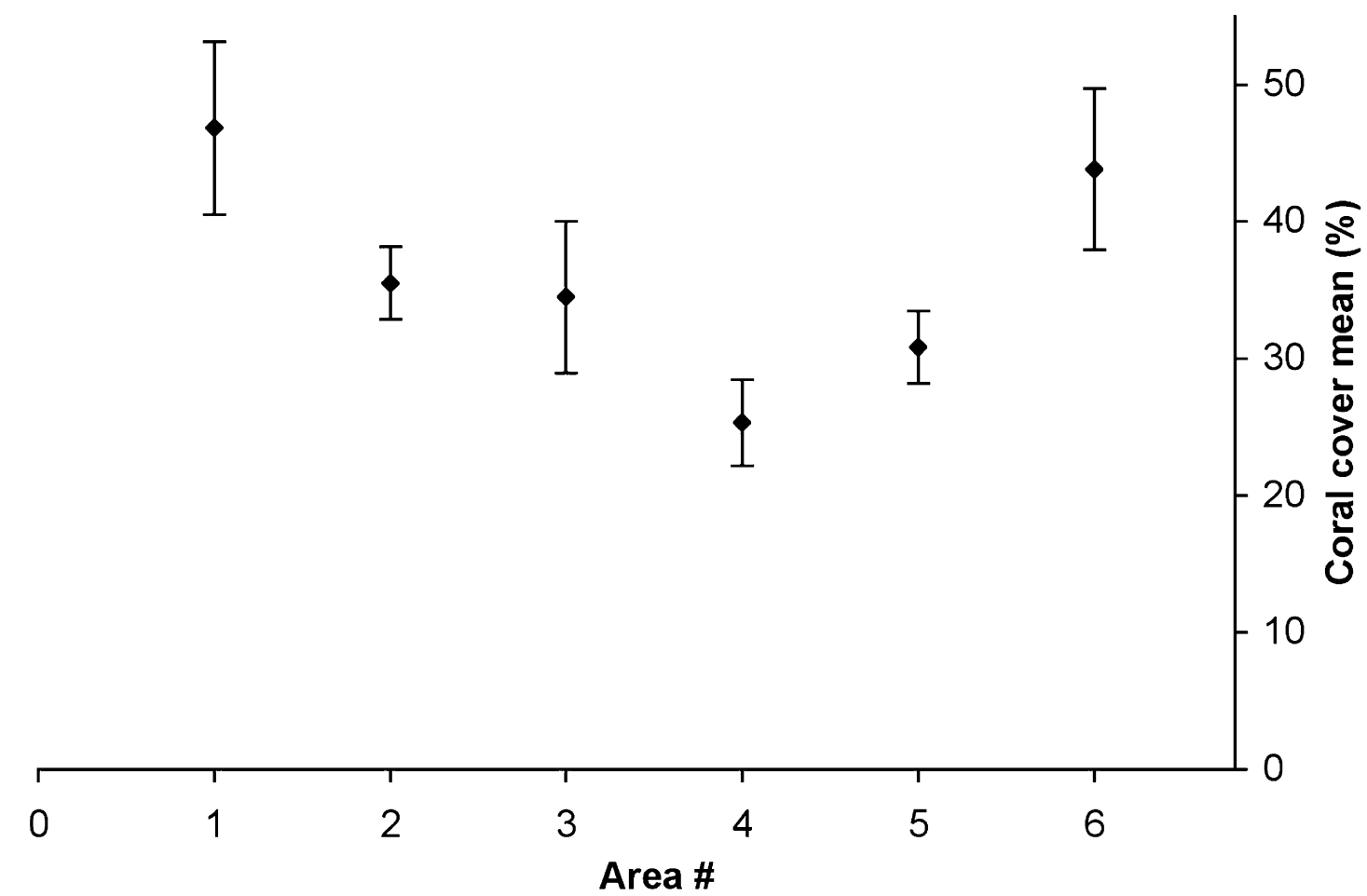

FIGURE 3. - Mean values and standard error bars of coral percent cover values randomly sampled into the raw data set gathered in each area

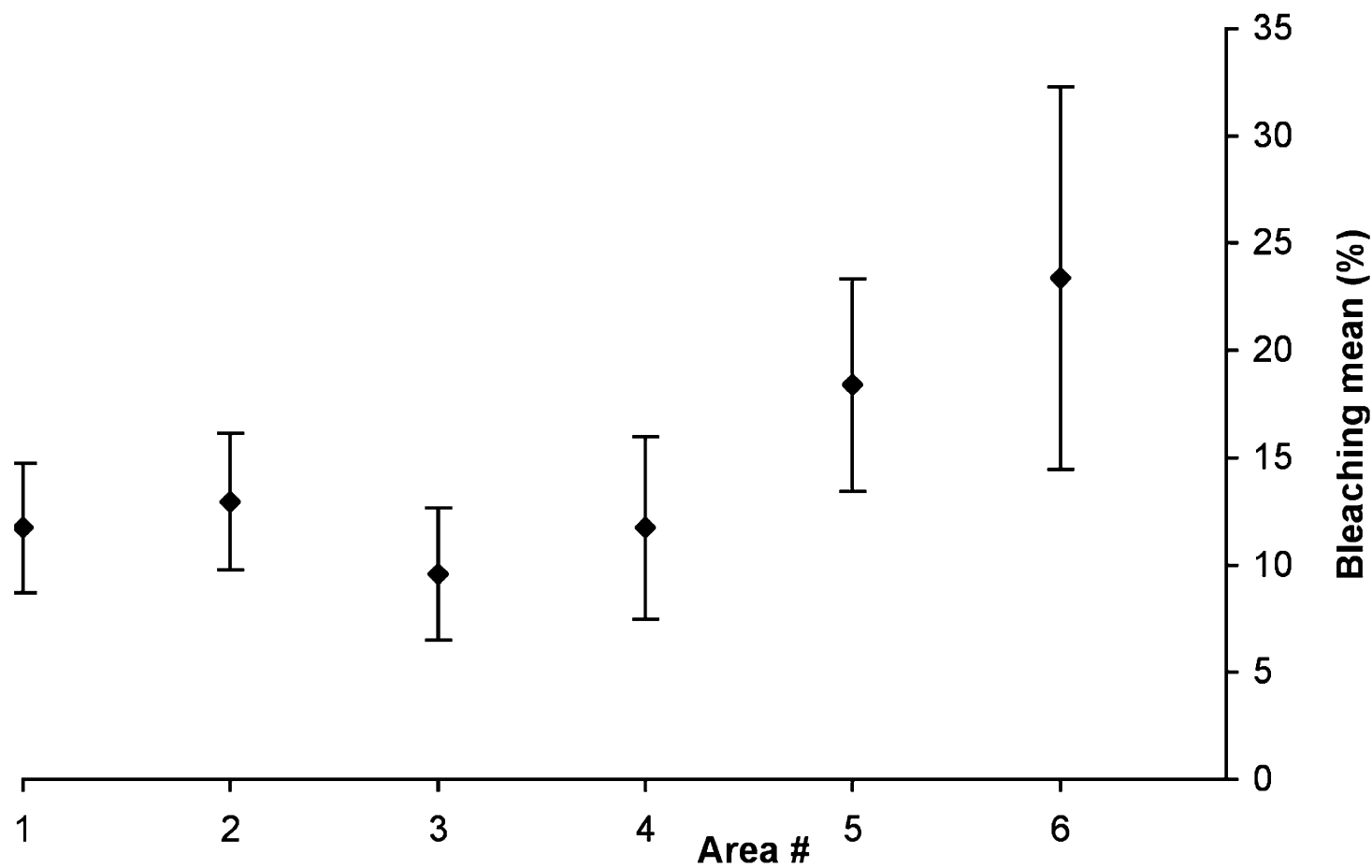

FIGURE 4. - Mean values and standard error bars of bleaching ratio values randomly sampled into the raw data set gathered in each area 
Bleaching events of corals developed in spatial scale, frequency and intensity during the last 3 decades (Goreau and Hayes, 1994). The most severe and unprecedented event happened in 1998 in relation with an El Nino event. Many coral reefs were destroyed in the whole intertropical zone (Wilkinson, 1998), from the Caribbean (Smith et al., 1998) to the Indian ocean (Spalding and Jarwi, 2002) and through the Pacific (Skirving and Guinotte, 2001). Socio economic impacts of bleaching events have been documented (Westmacott et al., 2000) and adaptation of corals to higher temperatures is a matter of controversy and research subject at the moment (Loya et al., 2001; Buddemeier and Fautin, 1993; Hoegh-Guldberg, 1999; HoeghGuldberg et al., 2002).

Bleaching events in Moorea have been recorded since 1991. The most important one was rightly in 1991 (Salvat, 1992; Gleason, 1993; Hoegh-Guldberg and Salvat, 1995) and observations were realized only on the north coast of Moorea. These observations were very precise and detailed according to the linear and quadrat methods we mentioned before. But they were applied only on very limited areas of the Moorea outer slope but not all around the island. The 2002 bleaching event compelled us to define this new Photo tow method to assess the impact of the phenomenon on outer slopes coral cover.

The main hypothesis to explain the coral coverage variations between the different portions of the outer slope around Moorea island is that differing swell conditions may well match the gradient pattern. Using the climatology records ( $c f$. Météo France), the swell impact on the coast of Moorea can be classified as following: very high and frequent on area 4 hit by south, south east and south west swell; high to moderate and less frequent on area 3 hit by south and south east swells but sheltered from east swell by the windward island of Tahiti; high and frequent on area 5 hit by south west dominant swell; moderate on area 1 and 6 only hit by the north boreal swells in summer time and moderate on area 2 sheltered from east swell by the windward island of Tahiti.

Causal relation with bleaching sensitivity is unclear and is probably more linked to coral community composition ie to the presence of coral genera more or less sensitive to water warming in the different areas surveyed. Subsequent line intersect surveys (done in august 2004 in areas 1, 2, 3, 5 and 6 as part of a marine protected area management plan) tend to confirm this hypothesis. They show in most cases, that Acro- pora, the most sensitive genus to bleaching (Salvat, 1992; Gleason, 1993; Hoegh-Guldberg and Salvat, 1995; Fujioka, 1999; Sugihara et al., 1999; Obura, 2001; Adjeroud et al., 2005) is more abundant in areas 2, 5 and 6 where the bleaching rate was highest in the photo tow study. Acropora ratios (percent occurrence of living Acropora colonies/total occurrence of alive genera) are $27.028 \%$ for area $6,20.69 \%$ for area 5, $24.69 \%$, for area $2,9.73 \%$ for area 1 , and $4.68 \%$ for area 3 . There is no genus surveys available for area 4.

\section{Conclusion}

The novel photo-tow method is an interesting approach for integrating multiple observations in monitoring the facies of coral colonies over distances. It can provide a quantitative analysis of the impact of disturbances at a whole reef scale, and more, as shown in our study of the effects of 2002 bleaching on the outer reefs of the whole island of Moorea. Photo tow method is a new tool for manager's guide (Marshall and Schuttenberg, 2006). Results obtained show that bleaching intensity is different around the island. Localized surveys of such and similar data on a reefscape or a reef zone could not have been representative at the whole reef scale, nor at the island scale, even in similar geomorphological and depth conditions. These results confirm the usefulness of the photo tow method to estimate coral reef status at such scales and conditions. This rapid method is useful to determine immediate impacts of natural events such as cyclones which occur suddently or bleaching event which have to be surveyed until the corals recover or died in order to measure the impact. Thanks to its resolution the method is applicable to dead corals after cyclones, and to bleached and non bleached coral during a bleaching event. The method can also be applied to count rapidly the invasion of the coral predator Acanthaster planci, the crown-of-starfish. Several technical adaptations can improve the method efficiency by using digital photography with large memory cards for getting more photographies in the same dive. Accuracy must also be improved to obtain information on coral species (for those that can be identified by photography) or coral 1 genera by varying the camera-bottom distance and the focal length of the lens (figure 5). 


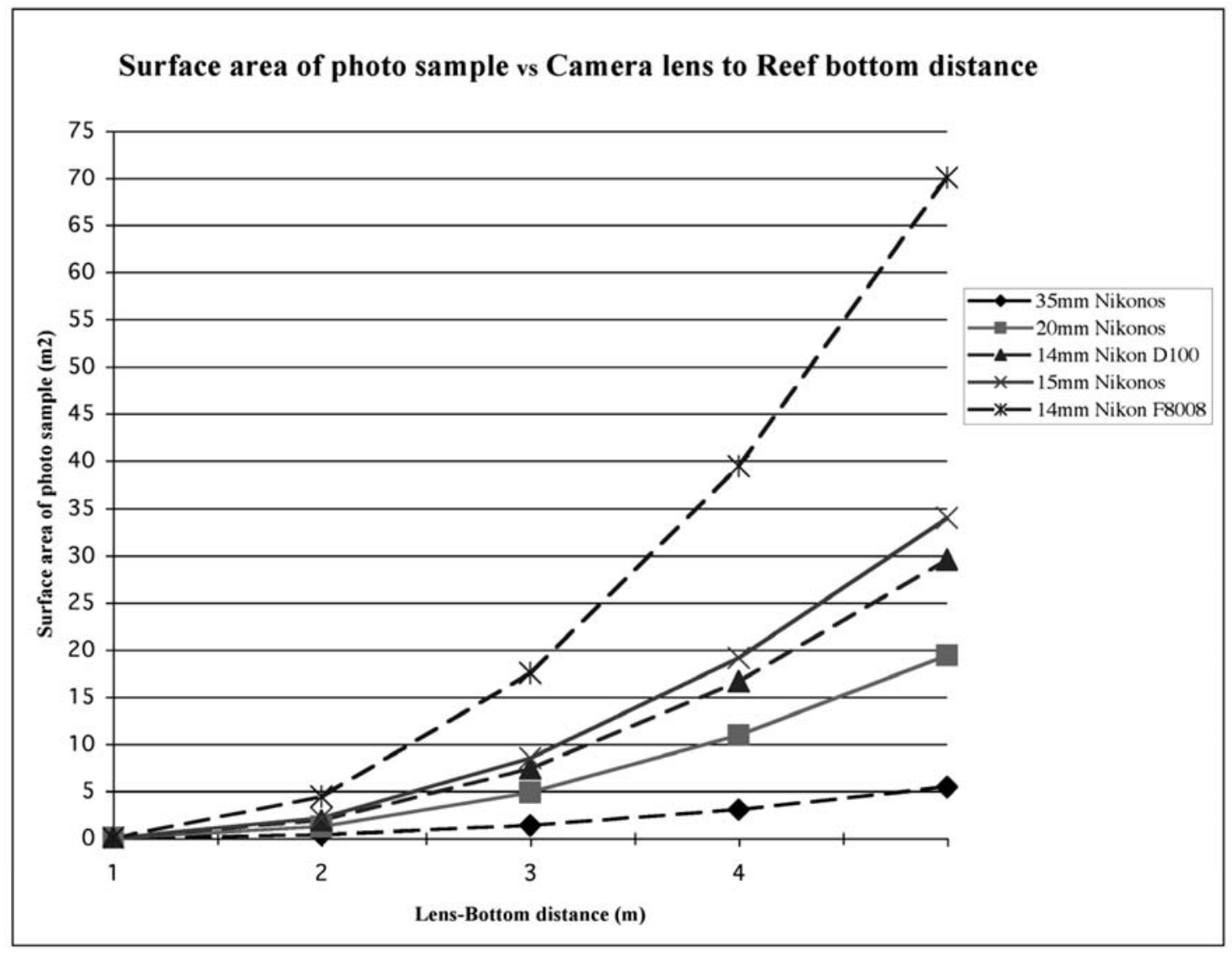

FiguRE 5. - Theoretical relationships between surface areas of photo samples and lens-bottom distance for 5 different lens potentialy used for photo-tow surveys

\section{BIBLIOGRAPHY}

Adjeroud M., Y. Chancerelle, M. Schrimm, T. Perez, D. Lecchini, R. Galzin and B. Salvat, 2005. Detecting the effects of natural disturbances on coral assemblages in French Polynesia: A decade survey at multiple scales, Aquating Living Resources 18, pp. 111-123.

Ammenberg P., L.T. Lindell and P. Kramer, 2002. Detection of coral bleaching using high spatial resolution satellite images, Proceedings of the $9^{\text {th }}$ Int. Coral Reef Symposium 2, pp. 997-1000.

AndréfouËT S., R. Berkelmans, L. Odriozola, T. Done, J. Oliver and F. Müller-Karger, 2002. Choosing the appropriate spatial resolution for monitoring coral bleaching events using remote sensing, Coral Reefs 21, pp. 147-154.

Aronson R.B., P.J. Edmunds, W.F. Precht, D.W.SWAnson and D.R. Levitan, 1994. Largescale, long-term monitoring of Caribbean coral reefs: Simple, quick, inexpensive techniques, Atoll Research Bulletin 421, pp. 1-19.

Buddemeier R.W. and D.G. FAutin, 1993. Coral bleaching as an adapatative mechanism, Bioscience 43, pp. 320-326.
Chabanet P., M. Adjeroud, S. Andréfouët, Y.M. Bozec, J. Ferraris, J.A. Garcìa-Charton and M. SCHRIMM, 2005. Human-induced physical disturbances and their indicators on coral reef habitats: A multi-scale approach, Aquating Living Resources 18 , pp. $215-230$.

Connell J.H., 1973. Population ecology of reefbuilding corals, in Jones O.A. and R. Endean (eds), Biology and geology of Coral Reefs, vol. II: Biology, New York, Academic press, pp 205245.

-, 1976. Competitive intercations and the species diversity of corals, in Mackie G.O. (ed.), Coelenterate Ecology and Behaviour, New York, Plenum Press, pp. 51-58.

EDMunds P. J., 2002. Long-term dynamics of coral reefs in St. John, US Virgin Islands, Coral Reefs 21, pp. 357-367.

EDMUnds P.J. and J.F. BRUNO, 1996. The importance of sampling scale in ecology: Kilometer-wide variation in coral reef communities, Marine Ecology Progress Series 143, pp. 165-171.

ENGLISH S., C. WiLKInsON and V. BAKER, 1997. Survey manual for tropical marine resources, Australian Institute of Marine Science, 390 p. 
FUJIOKA Y., 1999. Mass destruction of the hermatypic corals during a bleaching event in Ishigaki Islands, Southwestern Japan, Galaxea 1, pp. 41-50.

GLEASON M.G., 1993. Effects of disturbance on coral communities: Bleaching in Moorea, French Polynesia, Coral Reefs 12, pp. 193-201.

Goreau J. and Hayes R., 1994. Coral bleaching and ocean «hot spots», Ambio 23, pp. 176-180.

Hanisak M.D., S.M. Blair and J.K. ReI, 1989. Use the photogrametric techniques to monitor coral reef recovery following a major ship grounding, Diving for Science, pp. 119-135.

Hoegh-Guldberg O., 1999. Climate Change, coral bleaching and the future of the world's coral reefs, Marine Freshwater Research 50, pp. 839-866.

Hoegh-Guldberg O., R.J. Jones, S. Wards and W.K. LoH, 2002. Is coral bleaching really adaptive, Nature 415, pp. 601-602.

Hoegh-Guldberg O. and B. Salvat, 1995. Periodic mass-bleaching and elevated sea temperatures: Bleaching of outer reef slope communities in Moorea, French Polynesia. Marine. Ecology Progress Series 121, pp. 181-190.

Kenchington R.A., 1978. Visual surveys of large areas of coral reefs, in D.R. Stoddart and R.F. Johannes (eds), Coral Reefs: research method, Paris, UNESCO, pp. 149-162.

KolHer K., 2004. Coral Point Count with Excel extension ( $C P C E)$, University of Florida National Coral Reef Institute.

LoyA Y., 1978. Plotless and transect methods, in D.R. Stoddart and R.F. Johannes (eds), Coral Reefs: research methods, Paris, UNESCO, pp. 197-217.

Loya Y., K. Sakai, K. Yamazato, H. Sambali and R. VAN WoEsIK, 2001. Coral bleaching: the winners and the losers, Ecology letters 4, pp. 122-131.

Maragos J.E. and C.W. CooK, 1995. The 1991-1992 rapid ecological assessment of Palau's coral reef's, Coral Reefs 14, pp. 237-252.

Marsh L.M., R.H. Bradbury and R.E. ReICHELt, 1984. Determination of the physical parameters of coral distributions using line transect data, Coral Reefs 2, pp. 175-180.

Marshall P. and H. Schuttenberg, 2006. A reef manager's guide to coral bleaching, Great Barrier reef marine Park Authority, $164 \mathrm{p}$.

Mc Manus J.W., M.C.A. Ablan, S. Vergara, B.M. Vallejo, L.A.B. Menez, K.P.K. Reyes, M.L.G. Gorospe and L. Halmarick, 1997. Reefbase Aquanaut Survey Manual, World Fish Center, 61 p.

Miller S.L., D.W. Swanson and M. Chiappone, 2002. Multiple spatial scale assessment of coral reef and hard-bottom community structure in the Florida Keys National Marine Sanctuary, Proceedings of the $9^{\text {th }}$ International Coral Reef Symposium 1, pp. 69-74.

Mumby P.J., J.D. Hedley, J.R.M. Chisholm, C.D. Clark, H. Ripley and J. Jaubert, 2004. The cover of living and dead corals from airborne remote sensing, Coral Reefs 23, pp. 171-183.

Ninio R. and M.G. Meekan, 2002. Spatial patterns in benthic communities and the dynamics of a mosaic ecosystem on the Great Barrier Reef, Australia, Coral Reefs 21, pp. 95-103.

Obura D.O., 2001. Can differential bleaching and mortality among coral species offer useful indicators for assessment and management of reefs under stress?, Bulletin of Marine Science 69, pp. 421-442.

Salvat B., 1992. Blanchissement et mortalité des Scléractiniaires sur les récifs de Moorea (archipel de la Société) en 1991, Comptes rendus de l'Académie des Sciences, Paris, t. 314, série III, pp. 105-111.

Skirving W. and J. GuinotTe, 2001. The sea surface temperature story on the Great Barrier reef during the coral bleaching event of 1998, in E. Wolanski (éd.), Oceanographic processes of coral reefs: physical and biological links in the Great Barrier Reef, Bocaraton (Florida), CRC Press, pp. 301-314.

Smith A., C. Rogers and C. Bouchon, 1998. Status of coral reefs in the lesser Antilles, Western Atlantic, in C. Wilkinson (ed.), Status of Coral Reefs of the World, Townsville, Australian Institute of Marine Science, pp. 135-143.

Spalding M.D. and G.E. Jarwis, 2002. The impact of the 1998 coral mortality on reef fish communities in the Seychelles, Marine Pollution Bulletin 44, pp. 309-321.

Sugihara K., Y. Iryu and T. NAKAMORI, 1999. Coral bleaching, geological ranges, and adaptation to high sea surface temperatures, Galaxea 1, pp. 89-95.

WiLKInSON C., 1998. Status of coral reefs of the world 1998, Townsville, Australian Institute of Marine Science, pp. 1-184.

Westmacott S., H. Cesar, L. Pet-Soede and O. LinDEN, 2000. Coral bleaching in the Indian ocean: socio economic assessment of effects, in Cesar $\mathrm{H}$. (ed.), Collected essays on the economics of coral reefs, University of Kalmar (Sweden), CORDIO, pp. 94-106.

Yamano H. and M. TAmura, 2002. Can satellite sensors detect coral reef bleaching? A feasability study using radiative transfer models in air and water, Proceedings of the $9^{\text {th }}$ International Coral Reef Symposium 2, pp. 1025-1031.

Yamano H., M. Tamura, Y. Kuni and M. Hidaka, 2002. Hyperspectral remote sensing and radiative transfer simulation as a tool for monitoring coral reef health, Marine Technical Science Journal 36, pp. 4-13. 